\title{
Latin American Songs in the GDR and the East German Singer-Songwriter Repertoire (1970-2000): Gerhard Schöne's 'Meine Geschwister' in the Light of Translation Studies
}

\author{
CHRISTINA RICHTER-IBÁÑEZ
}

\begin{abstract}
Latin American folkloric-popular music had an impact on the music scenes of both Germanies, where singer-songwriters emerged and became interested in Chilean Nueva Canción, the Argentinian Movimiento del Nuevo Cancionero, and Cuban Nueva Trova in the 1970s. Particularly interesting in this context is the contact of some Latin American countries with the German Democratic Republic (GDR). Based on translation theory and articles on Nueva Canción in Europe, this article examines the Latin American presence at the Political Song Festival in East Berlin and analyses some publications that focus on this annual event. The article focuses on the singer-songwriter Gerhard Schöne, who during the 1980s, took Nicaragua as a political example, as is shown in songs, and who also composed German lyrics to melodies by Violeta Parra, Atahualpa Yupanqui, and Silvio Rodríguez, transferring the songs into a new context.
\end{abstract}

In 2000, the German songwriter Gerhard Schöne released a CD entitled Das Perlhuhn im Schnee (The Guinea Fowl in the Snow) with musicians Stefan Kling, Jörg Nassler, and Rainer Schwander. ${ }^{1}$ It contained a song called 'Meine Geschwister' ('My Siblings'). The German lyrics were written by Schöne, the arrangement was by Nassler. Both the melody and the idea of Schöne and Nassler's cover followed 'Los hermanos', a song recorded on LP for the first time by Atahualpa Yupanqui in $1969 .{ }^{2}$ Mercedes Sosa included it in her concerts in Argentina, most prominently in 1972 and 1982. ${ }^{3}$ This article explores the question of

Email: christina.richter-ibanez@uni-tuebingen.de

I am grateful to Lutz Kirchenwitz and Elke Bitterhof for information on the Festival of Political Song in Berlin as well as to Alexander Neumann who made his collection of the festival's newspaper available to me. Gerhard Schöne and Tobias Morgenstern added important information in interviews given in August and September 2019. I also want to thank Elke Steinhauser for transcriptions and Elizabeth Lee Hepach for her advice on language issues.

1 Gerhard Schöne, Das Perlhuhn im Schnee, CD, Buschfunk, LC 06312 00232, 2000.

2 Atahualpa Yupanqui, Preguntitas sobre Dios, LP, Le Chant Du Monde, LDX 74415, 1969; Atahualpa Yupanqui, Preguntan de donde soy, LP, RCA Victor, LSP 10405, 1969.

3 Illa Carillo-Rodríguez, 'Latinoamericana de Tucumán: Mercedes Sosa y los itinerarios de la música popular argentina en la larga década del sesenta', in Ese ardiente jardín de la República. Formación y desarticulación de un 'campo' cultural: Tucumán, 1880-1975, ed. Fabiola Orquera (Córdoba: Alción, 2010), 262. Mercedes Sosa, Mercedes Sosa en Argentina, 2 LP, Philips, 6388107/8, 1982. 
how a song such as 'Los hermanos' found its way into German, and especially, into East German repertoire. The process of being adopted as international repertoire is important for this and other Latin American tunes which, translated into German, developed an independent life in a new context. As a contribution to transatlantic music history, as well as to translation studies in music, the present article summarizes the state of research on the international dissemination of Latin American popular music in general, and particularly in regards to the Political Song Festival in the GDR. It subsequently examines Schöne's participation in the festival, showing to what extent Latin American realities served as role models during the decline of communism as echoed in songs. Finally, Schöne's adaptation will be examined more closely within this historical context.

The term 'translation' has become a widely used metaphor for transfer processes. Although, in the long history of translation theory, music in general and songs in particular have seldom being taken as research subjects. ${ }^{4}$ Nevertheless, the fields of translation studies and musicology have become closer in the twenty-first century; with recent work focusing on the translation of librettos and art songs, as well as on subtitling opera, questions of cultural and intersemiotic translation, untranslatability, and adaptation to various media as a creative process have become relevant. ${ }^{5}$ Lucile Desblache summarizes that, on the one hand, translation shapes music in many senses and, on the other, 'music has an impact on translation' ${ }^{6}$ She uses the term 'translation' in three ways: first, it stands for 'the process of transferring a text from one language ... into another', resulting in new products; second, it refers to the transmutation of musical elements or styles; and third, it is meant 'more broadly as a transformational tool used in music to convey meaning across boundaries', 7 including the sonic evocation of places as well as the dissemination of political messages. In analysing the reinterpretation of Latin American songs in the GDR, especially in Schöne's covers, all three notions are relevant. However, the sum of the changes in the translation of the lyrics and the musical reinterpretation leads to the creation of individual performances for East German audiences mostly unaware of the song's origins, these audiences received Latin American songs, translated and sung by Schöne after 1989, detached from the political context of their Latin American origin in the 1960s, 1970s, and 1980s. Nevertheless, Schöne's versions continued to convey values such as global awareness and cohesion removed from revolutionary ideals. The present article aims to draw attention to the cultural and political contexts which these particular translation processes have depended upon. The focus on translation and adaptation of popular tunes in new contexts reveals the wide variety of agents contributing to the process and the ways in which translators act as co-creators. To date, studies have sometimes considered that the translation of poetry and literature boomed in certain spaces and moments, that it played an essential role in the Cold War or in communist Eastern

4 For example, no entry on music in Mona Baker and Gabriela Saldanha, eds., Routledge Encyclopedia of Translation Studies (London: Routledge, 1998, 2nd edn 2009).

5 Şebnem Susam-Sarajeva, ed., Translation and Music (special issue: The Translator) 14/2 (2008). Helen Julia Minors, ed., Music, Text and Translation (London: Bloomsbury, 2013).

6 Lucile Desblache, Music and Translation. New Mediations in the Digital Age (London: Palgrave, 2019), 4.

7 Desblache, Music and Translation, 4. 
Europe, and that it had an impact on the international dissemination of protest songs. ${ }^{8}$ However, in the young field of music and translation studies, neither German nor Latin American repertoires have received focused attention, and the rather apolitical scene that German singer-songwriter Schöne belonged to has rarely been researched in depth. ${ }^{9}$

\section{Latin American musicians and folkloric-popular music in Europe: growing politicization and publicity}

After the 1973 military coup in Chile, recordings of Nueva Canción increased remarkably and musicians such as Quilapayún and Inti-Illimani reached an international market due to global attention and solidarity to the Chilean cause. However, Latin American folkloric-popular music was already successful in Europe by the late 1960s. As Fernando Rios argued, Argentinian musicians started playing South American tunes in Paris from the 1950s, mixing Andean instruments with elements from different regions in Latin America, while experimenting in locales of the Quartier Latine. ${ }^{10}$ The result, a kind of hybrid, stylized Andean music, was taken by the Parra family back to Chile; by the mid-1960s it gave birth to the political Nueva Canción movement with its pan-Latin Americanist style and attitude. Anti-US sentiments, together with the growing interest in the communist revolution in Cuba, and Ché Guevara's publicized capture and assassination in Bolivia in 1967, increased the French public's interest in Latin American music, which was associated with leftist political movements.

In his essays on the dissemination of Nueva Canción in Europe, Javier Rodríguez Aedo addressed the movement's political aspect, emphasizing that the performances of Chilean musicians in Europe were supported by socialist and communist movements. In German-speaking countries in particular, concert tours and the circulation of this music should be understood against the background of the Cold War. Rodríguez draws attention to the fact that France and Germany quickly became the points of entry of Nueva Canción into Europe around 1970. ${ }^{11}$ Quilapayún toured Europe and the Soviet Union in 1968. A tour with Isabel Parra through several countries followed in 1970. In 1971 and 1972, they took part together in the second and third Festival of Political Song in East Berlin. ${ }^{12}$ At the

8 Fruela Fernández and Jonathan Evans, eds., The Routledge Handbook of Translation and Politics (London: Routledge, 2018); Emily Lygo on the Cold War, Ioana Popa on communism in Eastern Europe and Şebnem Susam-Sarajeva on Music and politics.

9 Dietmar Elflein, 'In Germany after the War: Broadening the Discourse on the Liedermacher', in The Singer-Songwriter in Europe: Paradigms, Politics and Place, ed. Isabelle Marc and Stuart Green (London and New York: Routledge, 2016). Elflein states that women and non-political singer-songwriters are especially under-researched.

10 Cf. Fernando Rios, 'Le Flûte Indienne: The Early History of Andean Folkloric-Popular Music in France and its Impact on Nueva Canción', Latin American Music Review 29/2 (2008).

11 Javier Rodríguez Aedo, 'Trayectorias de La Nueva Canción Chilena en Europa (1968-1990)', in Palimpsestos Sonoros. Reflexiones sobre la Nueva Canción Chilena, ed. Eileen Karmy and Martín Farías (Santiago de Chile: Ceibo Ediciones, 2014), 223. Javier Rodríguez Aedo, 'La Nueva Canción Chilena: un ejemplo de circulación musical internacional (1968-1973)', Resonancias 20/39 (2016).

12 Rodríguez Aedo, 'Trayectorias de La Nueva Canción Chilena'; Rodríguez Aedo, 'La Nueva Canción Chilena'. Unless otherwise stated 'Berlin' in this paper refers to 'East Berlin'. 
same time, the Chilean and Cuban music scene intensified exchange with visits by Isabel and Angel Parra and Quilapayún to Cuba in 1967 and 1971, respectively, followed by Silvio Rodríguez and Pablo Milanés's trips to Chile in 1972. ${ }^{13}$ Inti-Illimani and Isabel Parra participated in the X World Festival of Youth and Students in East Berlin in 1973. Both Quilapayún and Inti-Illimani, as well as Isabel Parra, stayed in Europe after the coup of September 1973. Their exile was marked by growing publicity and massive concerts. Rodríguez's research, centred around the record labels that spread this music, shows that most of the original records of Nueva Canción were pressed in France and the two Germanies, while audiences in other European countries had access mostly to re-editions of those LPs. The most influential record labels were Amiga and Eterna in the GDR, Pläne in the FRG, and Le chant du monde in Paris; all of them had links to socialist or communist organizations.

\section{The Festival of Political Song in East Berlin and Latin American guests in the 1970s}

The participation of Isabel Parra and Quilapayún in the Festivals of Political Song in East Berlin provides evidence that Nueva Canción's European connections were established in the years prior to the coup in Chile and that it had a strong influence on the repertoire of other musical groups. The Berlin festival emerged out of the singing clubs associated to a GDR folk movement called 'Hootenanny', which was renamed and institutionalized in 1967 with the founding of the Oktoberklub and the simultaneous affiliation to the state organization Freie Deutsche Jugend (FDJ, Free German Youth). ${ }^{14}$ From 1970 to 1990, the Festival of Political Song represented the international left-wing singer-songwriter scene - including artists from the FRG but above all from Eastern Europe, Spain, and Latin America - it reflected political events taking place throughout the world and might be regarded as one of the few windows into the world for GDR audiences. Lutz Kirchenwitz, a participant in the festival and a witness to the scene of that period, reported in retrospect:

During a week, concerts took place in the largest halls of the city and were accompanied by discussions, colloquia, friend meetings (for example, Oktoberklub members invited foreign festival participants to their homes for breakfast), football tournaments, etc. It was a big event, a meeting of musical experts. In addition, participants, observers (artists, musicologists, journalists) came from the GDR, the FRG, Finland, Bulgaria, etc. Song festivals or left-wing cultural festivals also existed in other countries, and together they formed an international network. The Berlin festival was a window to the world, it was solidarity you could feel. ${ }^{15}$

13 Jan Fairley, “"There Is No Revolution Without Song”: “New song” in Latin America', in Music and Protest in 1968, ed. Beate Kutschke and Barley Norton (Cambridge: Cambridge University Press, 2013), 130-2.

14 Lutz Kirchenwitz, Folk, Chanson und Liedermacher in der DDR: Chronisten, Kritiker, Kaisergeburtstagssänger (Berlin: Dietz, 1993), 37-40.

15 Lutz Kirchenwitz, in Rote Lieder. Festival des politischen Liedes Berlin/DDR 1970-1990, ed. Lied und soziale Bewegungen e.V., 2nd edn (Berlin, 2011), 3, trans. C.R.I. 
In the 1971 and 1972 festival programmes, the guests were welcomed in five languages: German, English, Russian, French, and Spanish. In addition to Quilapayún and Isabel Parra, the festival featured Spanish-speaking artists such as Silvio Rodríguez from Cuba, Alí Primera from Venezuela, Manuel Fernando Zárate from Panama, the Quinteto Tiempo from Argentina, Aurora Lacasa from Spain, and mixed groups, such as Basta with members from Venezuela and the GDR. The Oktoberklub's visit to Cuba in 1971 had intensified personal and musical experiences, as well as relations to musicians who subsequently travelled to Berlin. ${ }^{16}$ Thus, not only was the musical exchange between Chile and Cuba intensified in the early 1970 s, ${ }^{17}$ but also the East German political song movement actively took part in the campaign.

Recordings of the festivals appeared on vinyl annually, each featuring two to three Latin American musicians. ${ }^{18}$ The book Intersongs. Festival des Politischen Liedes, released by the publisher Neues Leben in 1973, features all previous festival guests with a selection of transcribed and translated songs; the backgrounds of the songs are explained, and original lyrics, interlinear translations, as well as new German adaptations are also included. However, the editor, Sieglinde Mierau, relativizes the trustworthiness of the transcriptions in the volume's preface:

But what about the reliability of what is at hand: the musical notation, the original lyrics, the interlinear translations, the adaptations' suitability for singing? Nothing is reliable. An army of helpers remembers, listens to words and melodies from tapes, from discs, translates, adapts the texts, writes in languages which are not always mastered. The resulting interpretations change text and music. Critical attention is demanded of those who use them. ${ }^{19}$

Thus, Mierau stresses the collaborative effort in transcribing and the pitfalls of translating song lyrics. A good example is the German version of Luis Advis's 'Comienza la vida nueva' ('New Life Begins') included in Intersongs. Quilapayún had performed the song at the 1971 Festival of Political Song in Spanish and it circulated in the GDR on record. ${ }^{20}$ For the next year's festival, the Oktoberklub made a version in German. For the occasion, Regina Scheer, one of the club's lyricists, reflected on the legitimacy of free adaptation in a programme note:

In our opinion, it is allowed to sing songs in different versions and with changes according to the audience's demands as long as the song's essential meaning is not falsified. The same applies to our own songs if the circumstances and the

16 Sieglinde Mierau, ed., Intersongs. Festival des Politischen Liedes (Berlin: Neues Leben, 1973), 316.

17 Cf. Fairley, “"There Is No Revolution Without Song”, 130-2.

18 2. Festival des politischen Liedes. Wer wenn nicht wir, LP, Eterna 815060, 1971; 3. Festival des politischen Liedes, LP, Eterna 815058, 1972.

19 Mierau, Intersongs, 6.

20 2. Festival des politischen Liedes, LP. Cf. Rodríguez Aedo, 'La Nueva Canción Chilena'; Javier Rodríguez Aedo, 'El folklore como agente político: la Nueva Canción Chilena y la diplomacia musical (1970-1973)', Nuevo Mundo Mundos Nuevos. Images, mémoires et sons (2017), http://journals.openedition.org/nuevomundo/70611. 
audience change. To understand songs as something rigid, unchangeable is contrary to their essence. This is especially true for political songs. ${ }^{21}$

Consequently, several different translations circulated. One variation by Regina Birkholz in Intersongs was slightly changed for the Oktoberklub album $A h a,{ }^{22}$ while Heinz Kahlau made a different one for Carlos Rincón's 1975 textbook Gitarre des dämmernden Morgens, which included Chilean song lyrics. ${ }^{23}$

Ideas about international communism are clearly expressed in the preface to Intersongs, where Mierau traces similar themes among Latin American, German-speaking, and Soviet songwriters as well as musicians from other countries:

It is no coincidence that Chilean singer Isabel Parra calls Valentina Tereshkova for help in their fight against religious superstition in her country, and that the Soviet group Nikitin makes one of the greatest poets of Latin America [implied is Nicolás Guillén] a key witness of the Latin American history. It is no coincidence that Kurt Demmler in the GDR and Pablo Milanés in Cuba - and many others write songs about the death of Ho chi Minh. ${ }^{24}$

What is particularly striking about this quote is that Latin American examples are used to illustrate all three topics at stake. Mierau mentions Violeta Parra's poem 'Qué vamos a hacer' ('What are We Going to Do?') also known as 'Ayúdame Valentina' ('Help Me, Valentina'), which Isabel Parra set to music and which appeared in Intersongs in a translation by Helmut Stöhr as 'Walentina'. ${ }^{25}$ Here, the Soviet cosmonaut and first female in outer space, Valentina Tereshkova, is taken as a symbol of science and technological progress in order to fight against religious preachers and their beliefs. Nevertheless, the rejection of religious symbols was not complete in the festival since the song 'Camilo Torres' by Daniel Viglietti appeared in Intersongs under the literal translation of the alternative title 'Cruz de luz': 'Ein Kreuz aus Licht' ('A Cross of Light'). ${ }^{26}$

In 1973, instead of the Festival of Political Song, which usually took place in February, a World Festival of Youth and Students took place in Berlin in July and August. ${ }^{27}$ The LP of the event increased the popularity of the songs 'Venceremos' ('We Will Be Victorious'), by

21 Regina Scheer, 'Über Nachdichtung', in Unser 3. Tagesinformation zum 3. Festival des politischen Liedes. 1. Tag (festival newspaper Berlin 1972), 5, trans. C.R.I.

22 Cf. Mierau, Intersongs, 301-3. Oktoberklub. Aha. LP, Amiga 855325, 1973.

23 Cf. Carlos Rincón, Gitarre des dämmernden Morgens. Das Neue Chilenische Lied (Berlin: Aufbau, 1975), 76-9.

24 Mierau, Intersongs, 10.

25 Mierau, Intersongs, 314-15. Same translation in Rincón, Gitarre des dämmernden Morgens, 18-21. Isabel Parra's version musically differs from Violeta Parra's own recording and the lyrics are shorter due to the deletion of three verses, cf. Juan Pablo González, Fernando Carrasco, and Juan Antonio Sánchez, eds., Violeta Parra. Tres discos autorales (Santiago: Universidad Alberto Hurtado, 2018), 240-5.

26 3. Festival des politischen Liedes, LP. Mierau, Intersongs, 45-7. Camilo Torres was a Colombian Catholic priest, a forerunner of Liberation Theology, and radical socialist who died when fighting for the Ejército de Liberación Nacional, a guerrilla organization.

27 Politische Lieder. Originalaufnahmen von den Tagen des politischen Liedes zu den X. Weltfestspielen. LP, Eterna 815065, 1973. 
Inti-Illimani, and 'El pueblo unido' ('The People, United'), interpreted by the groups Quinteto Tiempo, Agitprop, and Oktoberklub. After the Chilean coup, in September of that year both of these very famous songs by the Chilean composer Sergio Ortega were additionally distributed on 7 -inch records. ${ }^{28}$ While the vinyl records of the festival before 1974 featured mostly musicians from the Southern Cone and Cuba, in the following years, musicians from Mexico and Central America, especially Nicaragua and El Salvador, were also recorded. Other countries, such as Colombia in 1978, or Brazil and Bolivia in 1985, played a subordinate role. Nicaraguan musicians became particularly appealing after the Sandinista revolution, and they remained present until 1987, when the solidarity action 'An ambulance for Nicaragua' was carried out as part of the festival in order to raise funds to help the country during the economic crisis of that year. ${ }^{29}$

\section{Latin American migrants, poetry, and music in the GDR . . .}

The regional focus on Chile, Cuba, and Nicaragua was the result of developing diplomatic relations and the immigration of Latin Americans to the GDR. According to political scientist Nikolaus Werz, diplomatic relations between Chile and the GDR intensified from 1971, and those with Cuba increased after Fidel Castro's visit in $1972 .{ }^{30}$ After the coup, more than two thousand Chileans exiled in the GDR. Among them were intellectuals and artists such as the music group Aparcoa, scholars, and students - such as Michelle Bachelet, who would later become president of Chile - who settled mainly in Rostock, Leipzig, and Potsdam. With regards to Nicaragua, the GDR recognized the revolutionary government as early as 1979 and established diplomatic relations with the Sandinista regime. Following these developments, the poetry series Poesiealbum released by the publishing house Neues Leben issued volumes on selected Latin American authors, including Pablo Neruda (vol. 53, 1972), Elvio Romero (vol. 62, 1972), Octavio Paz (vol. 72, 1973), Ernesto Cardenal (vol. 101, 1976), Nicolás Guillén (vol. 129, 1978), and César Vallejo (vol. 140, 1979). Consequently, Neues Leben was of relevance to the dissemination of both poetry and songs. In the same format, similar to Intersongs, the book Cantaré. Songs aus Lateinamerika (I Will Sing. Songs from Latin America) was published by Neues Leben in 1978. The concept of Cantaré seems to be inspired by the earlier Intersongs since introductory texts on music in Latin America are generally followed by chapters on individual performers and transcriptions of selected songs. The preface by the editors Carlos Rincón and Gerda Schattenberg-Rincón openly refers to Latin American revolutions, the struggle for political and social liberation, and the commitment of folkloric-music singers to it. ${ }^{31}$ Cantaré's editors were specialists in Ibero-American literature and had previously published translations of Federico García Lorca and Pablo Neruda in the GDR. Carlos Rincón was a Colombian scholar who studied literature in Leipzig, worked at the Akademie der Wissenschaften (Academy of Sciences)

28 Solidarität mit Chile. Originalaufnahmen vom Liedfestival 'Politische Lieder' zu den X. Single, Eterna 415130, 1973.

29 Tageszeitung vom 17. Festival des politischen Liedes Berlin 1987, FZ 2. Dienstag (festival newspaper), 17 February 1987, 6.

30 Nikolaus Werz, 'Lateinamerikaner in der DDR', Deutschland Archiv 42/5 (2009).

31 Carlos Rincón and Gerda Schattenberg-Rincón, Cantaré. Songs aus Lateinamerika (Berlin: Neues Leben, 1978), 5-8. 
of the GDR and later at the Universidad Central de Venezuela in Caracas. He became a personal consultant to Ernesto Cardenal when the latter was appointed Minister of Culture in Nicaragua in the late 1970s.

\section{... and repercussions in the FRG}

Cantaré found some distribution and further editions in both East and West Germany because it was simultaneously licensed by Weltkreis-Verlag Dortmund, which was part of the working group of socialist and communist publishers and booksellers in the FRG. Literary scholars sometimes refer to the Weltkreis as a 'Scheinverlag' (a masked publisher) sponsored by the GDR. ${ }^{32}$ In the Federal Republic, South American repertoire had already been heard at the Burg Waldeck festivals in the $1960 \mathrm{~s}^{33}$ and some songs had been included in youth songbooks. ${ }^{34}$ Events, such as the Tübinger Folk- und Liedermacher Festival, reflected on the political situation in Latin America and had topical concerts with musicians from Argentina, Bolivia, and Chile from 1975 to 1977. In 1978, the festival was dedicated to the Chilean songwriter Víctor Jara for various reasons; according to the organizers, the development of Latin American folkloric-popular music since the 1960s and the fact that Chilean singers were struggling 'for a more just society ${ }^{35}$ should have served as models for the folk movement in the FRG, which still remained self-absorbed and rarely participated in the 'international discussion on creating a new democratic popular culture'. ${ }^{36}$ More importantly, the focus on Latin America was the result of political circumstances - such as the military dictatorships in Argentina and Chile - or popular events - such as the FIFA World Cup in Argentina or the XI World Festival of Youth and Students in Cuba in 1978. The 1978 programme booklet contained articles on Chile, Paraguay, and Argentina, as well as translations of lyrics from songs by Jara, Guillén, and Viglietti. Against this background, the songbook Cantaré generated a lot of interest in West Germany. Furthermore, leftist social movements had an impact on the folk music scene in Germany, as reflected in the festival in Tübingen that focused on Nicaragua in 1981. These events sometimes included acts of solidarity with Latin American leftist regimes. ${ }^{37}$

From a different perspective, Christian musicians such as Peter Janssens, who had personal experiences with Liberation Theology and other political movements in Latin America, were

32 Julia Frohn, Literaturaustausch im geteilten Deutschland 1945-1972 (Berlin: Links, 2014), 299.

33 Played by the group Pontocs, cf. Holger Böning, 'Die Anfänge musikalischen Protests in der Bundesrepublik und der DDR: ausländische Einflüsse im politischen Lied', in Rebellische Musik. Gesellschaftlicher Protest und kultureller Wandel um 1968, ed. Arnold Jacobshagen and Markus Leniger (Köln: Dohr, 2007), 185-6.

34 E.g., Liederkiste. Liederbuch II des Student für Europa - Student für Berlin e.V., ed. Martin Ketels, Mary Jo Fink, and Ulrich Waßner, 2nd edn (Frankfurt a.M., 1977), including 'Canción del poder popular', 'Venceremos', and 'Te recuerdo Amanda' by Víctor Jara.

35 Programme booklet 4. Tübinger Festival 9.-11. Juni 1978, ed. Club Voltaire, Tübingen 1978, 23.

36 Programme booklet 4. Tübinger Festival 9.-11. Juni 1978, 23.

37 Cf. Eckard Holler, 'The Folk and Liedermacher Scene in the Federal Republic in the 1970s and 1980s', in Protest Song in East and West Germany Since the 1960s, ed. David Robb (Rochester, NY: Camden House, 2007), 157. 
also inspired by South American lyrics and tunes. ${ }^{38}$ Since Ernesto Cardenal's poetry was both translated and set to music, he became a role model for political and Christian activists, poets, and folk musicians in both West and East Germany. In the 1980s, acts of solidarity for Nicaragua were carried out in both Germanys, ${ }^{39}$ while the Nicaraguan way of combining socialism and democracy was seen with hope by people in the GDR, who were increasingly disillusioned with their own government. Singer Gerhard Schöne travelled to Nicaragua in 1987 and composed lyrics and songs inspired by his experiences in Latin America that he included in LPs, which were produced just before German reunification.

\section{Gerhard Schöne's participation in the Festival of Political Song, personal experiences in Nicaragua, and song translations}

As a protestant parson's son born in 1952, Schöne grew up listening to the singers from the Hootenanny Club, as well as to Lutheran hymns and popular music. He started as an avocational songwriter in the 1970s, completed an artistic degree through distance learning at the College of Music in Dresden and had his first record released by Amiga in 1981. When Schöne took part for the first time in the Festival of Political Song, he appeared as a singer-songwriter from the Lutheran church circle. According to Steffen Mensching:

it seemed to me that they [the festival's organizers] wanted to promote and even integrate an aspiring artist, although he didn't fit into the common scheme of the 'Red Songs'. . . . It sounded like: 'He actually doesn't fit in with us, but it would suit the festival well and especially in front of the foreign guests, if someone from the church participates, the Christian ally, so to speak'. The only GDR artists who had taken part in the festival before were those directly associated with the FDJ singing movement. Gerhard Schöne was the first performer in the festival to come from a completely different direction. ${ }^{40}$

Although in Latin America Liberation Theology and socialism were never at odds, which was obvious in the case of Nicaragua, in the GDR Christians were perceived negatively by the ruling party, the Socialist Unity Party of Germany. Accordingly, Schöne was suspiciously investigated due to his religious background and his regular concerts in churches. His participation in the Festival of Political Song in the 1980s demonstrated that by that time, the GDR singersongwriter scene had been growing and diversifying. Schöne's first performance at the festival was in a concert with Barbara Thalheim, Hans-Eckhard Wenzel, and others, on 15 February 1980. In the following year, the festival's newspaper featured him for the first time,

38 Cf. Peter Hahnen, Das 'Neue Geistliche Lied' als zeitgenössische Komponente christlicher Spiritualität (Münster: Lit, 1998), 422-43.

39 See examples above and advertisement in the programme booklet 10. Tübinger Festival 15.-17. Juni 1984, ed. Club Voltaire (Tübingen 1984).

40 Steffen Mensching quoted in Danuta Görnandt and Matthias Görnandt, Gerhard Schöne. Ich bin ein Gast auf Erden. Ansichten, Gespräche, Lieder (Berlin: Schwarzkopf \& Schwarzkopf 2012), 382-3, trans. C.R.I. 
mentioning his practice of inventing new words for well-known melodies. ${ }^{41}$ Since he was young, Schöne translated mainstream songs and modernized traditional hymns; he liked playing with words and acquired his musical skills by taking old songs as models. In the 1980s, he became especially famous for his own children's songs, for being a regular act at the 'Kinderkirmes' - a family concert during the Festival of Political Song - and for presenting original programmes for adults. In 1984, the festival newspaper announced that Schöne had started gathering children's songs from all over the world and he hoped the international guests at the festival would contribute new tunes to his collection. ${ }^{42}$ During the festival, he invited foreign musicians and their interpreters to his home in Berlin, asked them to sing children's songs, and recorded them along with the interpreters' explanations about the song's lyrics. Annette Walden, who served as an interpreter for Schöne, was key in understanding the Latin American repertoire. ${ }^{43}$ These activities resulted in Gerhard Schöne singt Kinderlieder aus aller Welt, a record released in 1987 that includes songs from Mexico, Cuba, Bolivia, and Venezuela, among others countries. The credits in the inner record sleeve mention José Miguel Márquez, who had participated in the Berlin festival for the first time in 1982, along with the exiled Chilean group Illapu. Márquez married Elke Bitterhof, a member of the Oktoberklub and TV presenter, who represented the GDR at the Comite International de la Nueva Canción (CINC: International New Song Committee), an organization founded in Cuba in 1982. ${ }^{44}$

In 1984, the festival record included Schöne's song 'Erinnerung' as well as Mercedes Sosa's first performance of Victor Heredia's 'Ventanita de laurel' in East Berlin. ${ }^{45}$ Sosa was celebrated as the great voice of Latin America and her return to Argentina from her exile in Europe for the legendary concerts of 1982 at the Teatro de la Ópera in Buenos Aires had been taken as a symbol of hope for the country after the dictatorship. ${ }^{46}$ The 1984 festival newspaper was filled with profiles of musicians from El Salvador, Bolivia, Nicaragua, and Chile, and included translated poems by Cardenal. Furthermore, a separate handout about the Nueva Canción and the CINC, which provided more song lyrics in German translations, was also in circulation. The omnipresence of Latin American artists at the festival continued until 1989, and included historical performances by Atahualpa Yupanqui and Silvio Rodríguez in 1985. The 1987 festival record ends with the very popular song 'Sólo le pido a Dios' ('The Only Thing I Ask God') by León Gieco and Sosa.

41 Mikel Maihher, 'Was zum Leben noch fehlt ...', in Tageszeitung des Festivals des politischen Liedes 13.2.81, FZ 6 (festival newspaper), 13 February 1981, 7.

42 aS [Astrid Salzmann], 'Gerhard Schöne', in Tageszeitung vom 14. Festival des politischen Liedes 13. Februar 1984, FZ 1 (festival newspaper), 13 February 1984, 5.

43 Gerhard Schöne, interview by the author. Meißen, 4 September 2019. See also the acknowledgement on the inner record sleeve of Gerhard Schöne singt Kinderlieder aus aller Welt, LP, Amiga Stereo 845312, 1987.

44 See handout La Nueva Canción at the 14th Festival des politischen Liedes 1984, private archive Alexander Neumann.

45 Rote Lieder. 14. Festival des politischen Liedes, LP, Amiga 845 284, 1984.

46 Hadi [Hans-Dieter Lucas], 'Mercedes Sosa (Argentinien)', in Tageszeitung vom 14. Festival des politischen Liedes 19. Februar 1984, FZ 7 (festival newspaper), 19 February 1984, 8. 
In July 1987, Schöne travelled to Managua for the first Nicaraguan book fair, which focused on children's literature. He travelled with the East German delegation and played children's songs in their booth. Although not officially allowed, the singer visited neighbourhoods, played on the streets, and participated in civic assemblies. At official receptions, he met or heard people he later sang about on his double album Du hast es nur noch nicht probiert (You Just Haven't Tried It Yet), a 1988 live recording from a concert tour with the group L'art de passage. ${ }^{47}$ The most famous song in this album is 'Mit dem Gesicht zum Volke' ('Facing the People'), which deals with grassroots democratic events. Schöne witnessed such events in Nicaragua and felt they were exemplary and worth imitating. This song remained a political anthem until the fall of the Berlin Wall and it is usually the only song by Schöne mentioned in general accounts of the East German singer-songwriter scene. ${ }^{48}$ In collaboration with L'art de passage, a band newly founded in 1987 that drew strong inspiration from jazz, as well as French and Latin American music, ${ }^{49}$ Schöne's recordings provided a new attractive sound to many listeners in the GDR. In lesser known songs, equally inspired by his Nicaraguan experience, such as 'Meine Rache' ('My Revenge'), from Du hast es nur noch nicht probiert, or 'Mädchen aus Managua' ('Girl from Managua') released in their following record, Lebenszeichen, the musicians of L'art de passage contributed to a combination of words, images, and music based on Latin American rhythms.

\section{Cover of 'Gracias a la vida'}

Lebenszeichen was the last album Schöne released with the GDR label Amiga. ${ }^{50}$ Its songs were written before the fall of communism in Eastern Europe, but they were recorded only in November and December 1989. Therefore, the record, with a cover showing a section of the recently torn down Berlin wall, is a true historical document. ${ }^{51}$ Global issues, a longing for a more humane and worthwhile life, and a future in freedom permeate the album thematically, punctuated by world music rhythms and sounds. Violeta Parra's 'Gracias a la vida' ('Thanks to Life') is the emblematic final song in a translation by Schöne called 'Liebes Leben, Danke'. Remarkably, it was the first time that Schöne recorded a complete translated

47 Gerhard Schöne, Gerhard Schöne, Live. Du hast es nur noch nicht probiert, live performance March 1988, prod. Karl Heinz Ocasek. 2 LP, Amiga, 845347/348, 1988.

48 David Robb, 'Political Song in the GDR: The Cat-and-Mouse Game with Censorship and Institutions', in Protest Song in East and West Germany Since the 1960s, ed. David Robb (Rochester, NY: Camden House, 2007), 246.

49 The founders of L'art de passage were accordionist and composer Tobias Morgenstern and guitarist Rainer Rohloff, both of them studied in Weimar. Early on, Cuban flutist and percussionist Justo Pérez also participated in the group. Tobias Morgenstern, interview by the author, Zollbrücke, 30 August 2019. Pérez studied in Berlin and played in various orchestras and groups there, cf. Victoria Eli Rodríguez, 'República Democrática Alemana (RDA): escena académica para los músicos cubanos (1960-1980)', in Trayectorias. Music between Latin America and Europe 1945-1970/Música entre América Latina y Europa 1945-1970. Ibero-Online 13 (2019), 30 and 37.

50 Gerhard Schöne, Lebenszeichen, LP, Amiga, 845364, 1990.

51 Javier Rodríguez Aedo, 'Recepción y apropiación estética de la obra musical de Violeta Parra en Europa (1954-1990)', Nuevo Mundo Mundos Nuevos. Images, mémoires et sons (2018), http://journals.openedition.org/nuevomundo/72183, assigns Schöne wrongly to the FRG. Since the GDR still existed in 1989 and 1990, this is designated as a GDR production. 
cover version on one of his own albums; earlier he had recorded children's songs and a short South African tune done as an encore in his preceding live double album. 'Gracias a la vida' was a very popular song since the 1970s. It was covered in Spain, Italy, France, Finland, and many other countries. Its lyrics, translated by Heinz Kahlau, were included in Gitarre des dämmernden Morgens and Cantaré. ${ }^{52}$ A version recorded by Joan Baez in 1975 became particularly popular, while Sosa's rendition during her 1982 return concerts to Argentina attained cult status. Despite the numerous ways he could have come across the Spanish version of the song, Schöne first heard it in Swedish on a TV show moderated by Gisela May, where its lyrics were explained. ${ }^{53}$ Inspired by the aesthetics of its lyrics and its expression of deep thankfulness, Schöne made an adaptation that clearly differed from Kahlau's translation. The song became so important to him that he recorded it several times in various arrangements. It finally found its way into his first songbook - in a version in 4/4 metre instead of the original 3/8 metre. ${ }^{54}$ However, in the first recording of the song in 1989, Schöne performs it in a mix of duple and triple metre in a sort of pan-Latin-flavoured arrangement: the first two verses are sung with guitar accompaniment only, the third sounds somehow Andean with transverse flute and charango, the fourth is a duo for voice and piano, while in the fifth and sixth verses all instruments interact, including the bass and Cuban percussions. The song ends with various repetitions of the hook line 'Gracias a la vida' forming a chorus sung by Schöne and a background choir in Spanish, leading to a calm coda accompanied by guitar, flute, and percussion. The ending in Schöne's version apparently owes more in melody and arrangement to Sosa's famous 1982 rendition, which also finishes with a repetition of the words 'Gracias a la vida' forming a melismatic four-verse coda, than to Parra's original.

A bilingual version, with the Uruguayan percussionist Rolo Rodríguez and a brilliant piano solo by Stefan Kling in an arrangement by Jörg Nassler, can be heard on Schöne's 2003 CD Fremde Federn (Borrowed Plumes). ${ }^{55}$ The album consists exclusively of translated covers of songs that have been meaningful in Schöne's life since the 1960s. Fremde Federn contains the cover of another Latin American song, Silvio Rodríguez's 'La maza', which was translated into German as 'Der Hammer' ('The Hammer'). After Rodríguez recorded this song on his 1982 LP Unicornio, it was covered by Mercedes Sosa and released in $1983 .^{56}$ Although the different processes of adaptation are difficult to trace in detail, it is evident that Schöne mainly picked up Latin American songs that had already become popular. He seems to have had a preference for songs sung by Sosa in particular. That is also the case of 'Los hermanos' ('The Brothers').

52 Rincón, Gitarre des dämmernden Morgens, 20-3; Rincón and Schattenberg-Rincón, Cantaré, 99-101.

53 Schöne, interview by the author. A Swedish translation was made in 1979 by Arja Saijonmaa, who did a Finnish one, too. Marie Bergman also recorded the song in Swedish in 1981.

54 Gerhard Schöne, Ralf Benschu and Jens Goldhardt, Komm herein in das Haus, prod. Manne Pokrandt, CD, Buschfunk, LC 06312 2076, 2017, final track. Gerhard Schöne, Markus Köhler, Andreas Schüßler, and Jörg Naßler, Lebenszeichen. Liederbuch, 5th edn (Berlin: Buschfunk, 1997). González et al., Violeta Parra, 132-47.

55 Gerhard Schöne, Fremde Federn, CD, Buschfunk, LC 06312 00042, 2003.

56 Mercedes Sosa, LP, Philips 814628-1, 1983. 


\section{'Los hermanos' - 'Meine Geschwister'}

Like 'Gracias a la vida', 'Los hermanos' was printed with musical notation in the songbook Cantaré, but the name of the author of the interlinear translation, titled 'Meine Brüder' ('My Brothers'), was not listed. ${ }^{57}$ A literal translation was printed in the newspaper of the 1985 Festival of Political Song, along with Yupanqui's profile on the occasion of his concert in Berlin. This translation is called 'Die Brüder' ('The Brothers') and no author is listed. ${ }^{58}$ Schöne might have heard Yupanqui when they played at the festival that year; ${ }^{59}$ however, he states that he became acquainted with the Argentinian singer and his songs through recordings (and the literal translations of the songs' lyrics, which used to be printed on record sleeves), and only later through concerts. ${ }^{60}$ Schöne's adaptation of 'Los hermanos' appeared in 2000. By this time, Yupanqui had passed away and his song had already been circulating for over thirty years. 'Los hermanos' first appeared on the 1969 albums Preguntan de donde soy and Preguntitas sobre Dios, the latter released by the French label Le Chant du monde, which had issued Yupanqui's records in Europe since $1950 .^{61}$ Although Yupanqui had stopped participating in the activities of the Communist Party, these connections did not simply disappear. $^{62}$ Both Cantaré and the newspaper of the Berlin festival wrote about Yupanqui as a legend, a myth, an ancient voice of Latin America, and an advocate of the poor. The texts also reminded readers of Yupanqui's exile in Paris and his performances with Edith Piaf in 1950, as they stressed the simple folkloric lyrics and melodies of his songs. ${ }^{63}$

'Los hermanos' was printed in Cantaré as a bridge between chapters about Yupanqui and Sosa, which made perfect sense since the latter adopted the song into her repertoire as early as 1972. According to Illa Carillo-Rodríguez, Sosa established her reputation as a Latin American and Argentinian singer by singing tunes by composers from various countries. Yupanqui's song was a perfect symbol of human solidarity, and followed by 'Canción con todos' ('Song with Everyone') by Armando Tejada Gómez and César Isella, it paved the way for strong anti-dictatorship political statements during her concert at Buenos Aires' Teatro Colón in August 1972. ${ }^{64}$ Sosa's recordings of 'Los hermanos' for

57 Rincón and Schattenberg-Rincón, Cantaré, 30-2.

58 Tageszeitung 15. Festival des politischen Liedes 15. Februar 1985, FZ 6 (festival newspaper), 15 February $1985,7$.

59 Cf. the article on Schöne in Tageszeitung 15. Festival des politischen Liedes 17. Februar 1985, FZ 8 (festival newspaper), 17 February 1985, 7.

60 Schöne, interview by the author.

61 In Yupanqui's Preguntitas sobre Dios, 'Los hermanos' is attributed to Pablo del Cerro, the pseudonym of Yupanqui's spouse, composer Antonieta Paula Pepin Fitzpatrick. In all other sources, including the Argentine copyright register SADAIC, 'Los hermanos' is solely attributed to Yupanqui.

62 Fabiola Orquera, 'From the Andes to Paris: Atahualpa Yupanqui, the Communist Party, and the Latin American Folksong Movement', in Red Strains. Music and Communism Outside the Communist Bloc, ed. Robert Adlington (Oxford: Oxford University Press, 2013), 115-18.

63 Rincón and Schattenberg-Rincón, Cantaré, 30-2. Tageszeitung 15. Festival des politischen Liedes 15. Februar 1985, FZ 6 (festival newspaper), 15 February 1985, 7.

64 Carillo-Rodríguez, 'Latinoamericana de Tucumán', 262. 
the 1972 album Hasta la Victoria and on her 1977 tribute to Yupanqui re-ignited its popularity. $^{65}$

Schöne's lyrics in 'Meine Geschwister' differ from the literal translations given in the Berlin festival newspaper and Cantaré, although certain keywords suggest he was familiar with the latter. The finest innovation is in the title and first verse, where Schöne uses the German 'Geschwister' ('siblings') instead of 'Brüder' ('brothers') to translate the word 'hermanos', which in Spanish stands as plural for a more comprehensive 'men and women'. In general, the first two stanzas are close translations of the original song, while the following couplets depart from the original lyrics. Nevertheless, the structure of the poem, the number of syllables and verses as well as the musical form (that of a milonga) were fundamentally unchanged. Nassler's arrangement begins with a guitar introduction that sets the tone for Schöne gently singing, which differs from both Yupanqui and Sosa's rough and declamatory vocal deliveries in their 1970s recordings. The beginning of Schöne's version might be inspired by Sosa's 1982 version, which makes much more use of vibrato and soft singing accompanied by guitar and percussion, but later, in the second section, it becomes livelier, with flute, bass, piano, and light percussion (cymbals, cajón, etc.) determining the mood. After the final verse, Nassler adds an extensive instrumental postlude.

\section{Conclusion}

When asked about his relation to Latin American songs in an interview, Schöne directly mentioned recordings of Silvio Rodríguez, Atahualpa Yupanqui, and Violeta Parra as well as the Festival of Political Song in Berlin, where interpreters translated the lyrics of the songs to the audience. With the help of this mediation, Schöne noticed that these authors had important things to say and that their music was fascinating. ${ }^{66}$ As described, there were several different translations of the lyrics of songs such as 'Los hermanos', which also had its melody transcribed in a songbook. Schöne confirmed that he knew Cantaré and especially appreciated the translations given therein by Bettina Wegner, as he believed they were often well done musically, especially since Wegner was a singer herself. As a singer-songwriter with a Christian background, Schöne adapted songs that spoke of humane ways of life, hope, and global solidarity in translations that sought to maintain the main ideas behind the original songs. These arrangements by Nassler and others also maintained what they felt were characteristic elements of the origins of the tunes by using mainly guitar accompaniment and percussions, charango and flute, as well as including native Spanish speakers singing the original lyrics at certain moments of the song, usually during refrains or final choruses. Tobias Morgenstern, accordionist and founder of L'art de passage, said in an interview that he often made arrangements taking the original recordings as a point of departure, usually copying characteristic stylistic features, such as a catchy bass line, besides adding his own ideas. ${ }^{67}$

65 Mercedes Sosa, Hasta la Victoria, LP, Philips, 6347068, 1972; Mercedes Sosa, Mercedes Sosa interpreta a Atahualpa Yupanqui. LP, Philips, 6347318, 1977.

66 Schöne, interview by the author.

67 Morgenstern, interview by the author. 
The musicians never hid the provenance of the music, but trained themselves in new techniques and made these songs into their own, which inspired listeners around the peaceful revolution and after the end of the GDR.

Thus, the three approaches to translation discussed by Desblache are apparent in this repertory: 1) the lyrics were transferred from one language to the other by professional translators - various persons transcribed the lyrics and printed them in textbooks, Schöne recorded verbal explanations of the song's topics on tape when international musicians visited him, or he came across versions in a third language (as in the case of the Swedish version of 'Gracias a la vida'); 2) general musical elements such as melody, vocal expression, and instrumental arrangement were maintained while stylistic details were changed and adapted;3) the general ideas of the songs (e.g., brotherhood, thankfulness to life, engagement) were conveyed across boundaries, first alongside cultural events with political significance, and after 1989 in more liberal circumstances, when people in East Germany were forced to re-orientate themselves in a changed society. For an audience unaware of the original political meaning of many of these songs, they became significant in new ideological and political contexts. Thus, in the case of Schöne, the historical contingency of international communism, especially the boom of translations around the Festival of Political Song, became the foundation for his adaptations. Nevertheless, he also carried some of these songs into the new millennium without maintaining their original political intention. Therefore, songs such as 'Meine Geschwister', 'Der Hammer', and 'Liebes Leben, Danke' were perceived simply as odes to humanist action, social coherence, gratitude, and faith, detached from any associations to communist and revolutionary struggle.

\section{Bibliography}

Baker, Mona and Gabriela Saldanha, eds. Routledge Encyclopedia of Translation Studies. London: Routledge, 1998, 2nd edn 2009.

Böning, Holger. 'Die Anfänge musikalischen Protests in der Bundesrepublik und der DDR: ausländische Einflüsse im politischen Lied', in Rebellische Musik. Gesellschaftlicher Protest und kultureller Wandel um 1968, ed. Arnold Jacobshagen and Markus Leniger. Köln: Dohr, 2007. 181-91.

Carillo-Rodríguez, Illa. 'Latinoamericana de Tucumán: Mercedes Sosa y los itinerarios de la música popular argentina en la larga década del sesenta', in Ese ardiente jardín de la República. Formación y desarticulación de un 'campo' cultural: Tucumán, 1880-1975, ed. Fabiola Orquera. Córdoba: Alción, 2010. 239-66.

Desblache, Lucile. Music and Translation. New Mediations in the Digital Age. London: Palgrave, 2019.

Elflein, Dietmar. 'In Germany after the War: Broadening the Discourse on the Liedermacher', in The Singer-Songwriter in Europe: Paradigms, Politics and Place, ed. Isabelle Marc and Stuart Green. London and New York: Routledge, 2016. 109-21.

Eli Rodríguez, Victoria. 'República Democrática Alemana (RDA): escena académica para los músicos cubanos (1960-1980)', in Trayectorias. Music between Latin America and Europe 1945-1970/Música entre América Latina y Europa 1945-1970. Ibero-Online 13 (2019). 29-39. www.iai.spk-berlin.de/fileadmin/dokumentenbibliothek/Ibero-Online/Ibero_Online_13_Trayectorias.pdf (accessed 17 February 2020).

Fairley, Jan. “"There Is No Revolution Without Song”: “New song” in Latin America', in Music and Protest in 1968, ed. Beate Kutschke and Barley Norton. Cambridge: Cambridge University Press, 2013. 119-36.

Frohn, Julia. Literaturaustausch im geteilten Deutschland 1945-1972. Berlin: Links, 2014.

Fruela Fernández and Jonathan Evans, eds. The Routledge Handbook of Translation and Politics. London: Routledge, 2018.

González, Juan Pablo, Fernando Carrasco, and Juan Antonio Sánchez, eds. Violeta Parra. Tres discos autorales. Santiago: Universidad Alberto Hurtado, 2018. 
Görnandt, Danuta and Matthias Görnandt. Gerhard Schöne. Ich bin ein Gast auf Erden. Ansichten, Gespräche, Lieder. Berlin: Schwarzkopf\&Schwarzkopf, 2012 (1st edn 2000).

Hahnen, Peter. Das 'Neue Geistliche Lied' als zeitgenössische Komponente christlicher Spiritualität. Münster: Lit, 1998.

Holler, Eckard. 'The Folk and Liedermacher Scene in the Federal Republic in the 1970s and 1980s', in Protest Song in East and West Germany Since the 1960s, ed. David Robb. Rochester, NY: Camden House, 2007. 133-67.

Ketels, Martin, Mary Jo Fink, and Ulrich Waßner, eds. Liederkiste. Liederbuch II des Student für Europa - Student für Berlin e. V., 2nd edn. Frankfurt a. M., 1977.

Kirchenwitz, Lutz. Folk, Chanson und Liedermacher in der DDR: Chronisten, Kritiker, Kaisergeburtstagssänger. Berlin: Dietz, 1993.

- In Rote Lieder. Festival des politischen Liedes Berlin/DDR 1970-1990, ed. Lied und soziale Bewegungen e.V., 2nd edn. Berlin, 2011.

Mierau, Sieglinde, ed. Intersongs. Festival des Politischen Liedes. Berlin: Neues Leben, 1973.

Minors, Helen Julia, ed. Music, Text and Translation. London: Bloomsbury, 2013.

Morgenstern, Tobias. Interview by the author. Zollbrücke, 30 August 2019.

Orquera, Fabiola. 'From the Andes to Paris: Atahualpa Yupanqui, the Communist Party, and the Latin American Folksong Movement', in Red Strains. Music and Communism Outside the Communist Bloc, ed. Robert Adlington (Proceedings of the British Academy 185). Oxford: Oxford University Press, 2013. 105-18.

Rincón, Carlos. Gitarre des dämmernden Morgens. Das Neue Chilenische Lied. Berlin: Aufbau, 1975.

Rincón, Carlos and Gerda Schattenberg-Rincón. Cantaré. Songs aus Lateinamerika. Berlin: Neues Leben; Dortmund: Weltkreis, 1978.

Rios, Fernando. 'Le Flûte Indienne: The Early History of Andean Folkloric-Popular Music in France and its Impact on Nueva Canción'. Latin American Music Review 29/2 (2008). 145-89.

Robb, David. 'Political Song in the GDR: The Cat-and-Mouse Game with Censorship and Institutions', in Protest Song in East and West Germany Since the 1960s, ed. David Robb. Rochester, NY: Camden House, 2007. $227-54$.

Rodríguez Aedo, Javier. 'Trayectorias de La Nueva Canción Chilena En Europa (1968-1990)', in Palimpsestos Sonoros. Reflexiones sobre la Nueva Canción Chilena, ed. Eileen Karmy and Martín Farías. Santiago de Chile: Ceibo Ediciones, 2014. 219-38.

—. 'La Nueva Canción Chilena: un ejemplo de circulación musical internacional (1968-1973)'. Resonancias 20/39 (2016), 63-91. http://resonancias.uc.cl/pt/N\%C2\%BA-39/la-nueva-cancion-chilena-un-ejemplo-de-circulacion-musical-internacional-1968-1973-pt.html. DOI: 10.7764/res.2016.39.4 (accessed 22 February 2019).

—. 'El folklore como agente político: la Nueva Canción Chilena y la diplomacia musical (1970-1973)'. Nuevo Mundo Mundos Nuevos. Images, mémoires et sons (2017). http://journals.openedition.org/nuevomundo/70611. DOI: 10.4000/nuevomundo.70611 (accessed 26 February 2019).

—. 'Recepción y apropiación estética de la obra musical de Violeta Parra en Europa (1954-1990)'. Nuevo Mundo Mundos Nuevos. Images, mémoires et sons (2018). http://journals.openedition.org/nuevomundo/ 72183. DOI: 10.4000/nuevomundo.72183 (accessed 1 February 2019).

Scheer, Regina. 'Über Nachdichtung', in Unser 3. Tagesinformation zum 3. Festival des politischen Liedes. 1. Tag. Berlin, 1972.

Schöne, Gerhard. Interview by the author. Meißen, 4 September 2019.

Schöne, Gerhard, Markus Köhler, Andreas Schüßler, and Jörg Naßler. Lebenszeichen. Liederbuch, 5th edn. Berlin: Buschfunk, 1997.

Susam-Sarajeva, Şebnem, ed. Translation and Music (special issue: The Translator) 14/2 (2008).

Werz, Nikolaus. 'Lateinamerikaner in der DDR'. Deutschland Archiv 42/5 (2009), 846-55.

\section{Discography}

Baez, Joan. Gracias a la Vida. Joan Baez canta en español. Prod. Joan Baez and Henry Lewy. LP, A\&M, SP 3614, 1974; CD, A\&M, 393614-2, [n.d.].

2. Festival des politischen Liedes. Wer wenn nicht wir. LP, Eterna 815060, 1971.

3. Festival des politischen Liedes. LP, Eterna 815058, 1972.

Oktoberklub. Aha. LP, Amiga 855325, 1973.

Politische Lieder. Originalaufnahmen von den Tagen des politischen Liedes zu den X. Weltfestspielen der Jugend und Studenten Berlin 1973. Hauptstadt der DDR. LP, Eterna 815065, 1973.

Rote Lieder. 14. Festival des politischen Liedes. LP, Amiga 845 284, 1984.

Schöne, Gerhard. Gerhard Schöne singt Kinderlieder aus aller Welt. LP, Amiga Stereo 845312, 1987.

Schöne, Gerhard. Lebenszeichen. LP, Amiga, 845364, 1990; CD, Amiga, 74321192922.

—. Das Perlhuhn im Schnee. CD, Buschfunk, LC 06312 00232, 2000. 
Live. Du hast es nur noch nicht probiert. Live performance March 1988, prod. Karl Heinz Ocasek. 2 LP, Amiga, 845347/348, 1988; CD Buschfunk 8037-2, 2002.

Fremde Federn. CD, Buschfunk, LC 06312 00042, 2003.

Schöne, Gerhard, Ralf Benschu, and Jens Goldhardt. Komm herein in das Haus. Prod. Manne Pokrandt. CD, Buschfunk, LC 06312 2076, 2017.

Solidarität mit Chile. Originalaufnahmen vom Liedfestival 'Politische Lieder' zu den X. Single, Eterna 415130, 1973. Sosa, Mercedes. Hasta la Victoria. LP, Philips, 6347068, 1972.

- Mercedes Sosa interpreta a Atahualpa Yupanqui. LP, Philips, 6347318, 1977.

. Mercedes Sosa en Argentina. 2 LP, Philips, 6388107/8, 1982; CD remastered, Universal, 018710-2, 2002.

Mercedes Sosa. LP, Philips 814628-1, 1983.

Yupanqui, Atahualpa. Preguntan de donde soy. LP, RCA Victor, LSP 10405, 1969.

. Preguntitas sobre Dios. LP, Le Chant Du Monde, LDX 74415, 1969. 